\title{
PROFESI GURU
}

\author{
Muhamad Dejan Rahman Algifari \\ Email: dejanraman28@gmail.com \\ Program Studi Pendidikan Sejarah Fakultas Keguruan dan Ilmu Pendidikan \\ Universitas Lambung Mangkurat \\ Banjarmasin
}

\begin{abstract}
Abstrak
Secara logik, setiap usaha pengembangan profesi (professionalization) harus bertolak dari konstruk profesi, untuk kemudian bergerak ke arah substansi spesifik bidangnya. Diletakkan dalam konteks pengembangan profesionalisme keguruan, maka setiap pembahasan konstruk profesi harus diikuti dengan penemukenalan muatan spesifik bidang keguruan. Lebih khusus lagi, penemukenalan muatan didasarkan pada khalayak sasaran profesi tersebut. Profesional adalah pekerjaan atau kegiatan yang dilakukan oleh seseorang dan menjadi sumber penghasilan kehidupan yang memerlukan keahlian, kemahiran, atau kecakapan yang memenuhi standar mutu atau norma tertentu serta memerlukan pendidikan profesi. Tak diragukan, guru merupakan pekerjaan dan sudah menjadi sumber penghasilan bagi begitu banyak orang, serta memerlukan keahlian berstandar mutu atau norma tertentu. Kompetensi guru meliputi kompetensi pedagogik, kompetensi kepribadian, kompetensi sosial, dan kompetensi profesional yang diperoleh melalui pendidikan profesi. Kompetensi pedagogik menunjuk pada kemampuan mengelola pembelajaran peserta didik. Kompetensi kepribadian menunjuk pada kemampuan kepribadian yang mantap, berakhlak mulia, arif, dan berwibawa serta menjadi teladan peserta didik. Kompetensi profesional menunjuk pada kemampuan penguasaan materi pelajaran secara luas dan mendalam. Kompetensi sosial menunjuk kemampuan guru untuk berkomunikasi dan berinteraksi secara efektif dan efisien dengan peserta didik, sesama guru, orangtua/wali peserta didik, dan masyarakat sekitar.
\end{abstract}




\section{PENDAHULUAN}

Pada pendahuluan ini, pembahasan akan berkaitan dengan konsep profesi dan profesi keguruaan. Profesi Secara etimologi berasal dari kata profession yang berarti pekerjaan. Professional artinya orang yang ahli atau tenaga ahli. Professionalism artinya sifat professional. (John M. Echols \& Hassan Shadily, 1990: 449). Dalam Kamus Besar Bahasa Indonesia, istilah profesionalisasi ditemukan sebagai berikut: Profesi adalah bidang pekerjaan yang dilandasi pendidikan keahlian (keterampilan, kejuruan dan sebagainya) tertentu. Profesional adalah (1) bersangkutan dengan profesi, (2) memerlukan kepandaian khusus untuk menjalankannya dan (3) mengharuskan adanya pembayaran untuk melakukannya Profesionalisasi adalah proses membuat suatu badan organisasi agar menjadi professional. (Depdiknas, 2005: 897). Dapat di artikan bahwa konsep profesi ialah suatu pekerjaan atau jabatan yan menuntut keahlian, yang didapatkan melalui pendidikan dan tidak semua orang dapat yang namanya profesi. Jika ingin mendapatkan suatu profesi, harus mengikuti pendidikan dan pelatihan khusus.

Guru merupakan suatu profesi, yang berarti suatu jabatan yang memerlukan keahlian khusus sebagai guru dan tidak dapat dilakukan oleh sembarang orang diluar bidang pendidikan. Guru perlu menguasai berbagai hal yang berhubungan dengan kemampuan professional yang dimilikinya, karena seorang suru sering dijadikan tokoh teladan bagi para pesetra didiknya. Menurut Noor Jamaluddin (1978: 1) Guru adalah pendidik, yaitu orang dewasa yang bertanggung jawab memberi bimbingan atau bantuan kepada anak didik dalam perkembangan jasmani dan rohaninya agar mencapai kedewasaannya, mampu berdiri sendiri dapat melaksanakan tugasnya sebagai makhluk Allah khalifah di muka bumi, sebagai makhluk sosial dan individu yang sanggup berdiri sendiri.

\section{PERAN GURU SEBAGAI SEBUAH PROFESI}

Guru dapat digolongkan sebagai sebuah profesi karena peran seorang guru ialah mendidik anak peserta didiknya dan mendidik peserta didik agar menjadi seseorang yang baik diperlukan peran seorang guru yang profesional. Tugas kemanusiaan satu di antara 
tugas guru, sisi ini tidak bisa guru abaikan, karena guru harus terlibat dengan kehidupan di masyarakat dengan interaksi sosial. Guru dalam menjalankan tugas profesionalnya mempunyai tugas dan tanggung jawab yang tidak ringan. Untuk itu, guru harus memiliki dan menguasai kompetensinya dan sekaligus mengetahui hak dan kewajibannya sehingga ia menjadi sosok guru yang betul-betul profesional (Shabir, 2015: 222-223). Guru wajib yang namanya menanamkan nilai-nilai kemanusiaan kepada peserta didik. Pada bidang kemasyarakatan guru mempunyai tugas mendidik dan mengajar masyarakat untuk menjadi warga negara Indonesia yang bermoral pancasila. Maka tugas guru tidak hanya sebatas dinding sekolah, tetapi juga sebagai penghubung antara sekolah dan masyarakat (Djamarah, 2000: 37).

Dalam Undang-Undang No. 14 Tahun 2005, dikatakan guru adalah pendidik profesional dengan tugas utama mendidik, mengajar, membimbing, mengarahkan, melatih, menilai, dan mengevaluasi peserta didik pada pendidikan anak usia dini jalur pendidikan formal, pendidikan dasar, dan pendidikan menengah. Jika diidentifikasi dari filosofi pendidikan Indonesia yang dicetuskan Ki Hadjar Dewantara "ing ngarso sung tulodo, ing madya mangun karso, tutwuri handayani" maka peran guru adalah sebagai:

a. Role model (ing ngarso sung tulodo), memberikan teladan kepada siswa karena fungsi guru menjadi pemimpin siswa dalam kegiatan pembelajaran.

b. Motor penggerak (ing madya mangun karso), guru harus menjadi penggerak inovasi dalam proses pendidikan dan penggerak peradaban dengan cara mengarahkan siswa untuk melakukan yang benar.

c. Motivator (tutwuri handayani), mampu memberikan dorongan semangat kepada siswa untuk mengadapi setiap persoalan dan mempelajari nilai-nilai kehidupan.

Djamarah(2000: 42-49) menguraikan banyak peranan yang dijalankan guru sebagai pendidik, atau siapa saja yang telah menerjunkan diri menjadi guru.
a. Korektor
b. Inspirator
c. Informan 
d. Organisator

e. Motivator

f. Inisiator

g. Fasilitator

h. Pembimbing

i. Demonstrator

j. Pengelola kelas

k. Mediator

1. Supervisor

m. Evaluator

Hak dan kewajiban guru ini dituangkan dalam UU No. 14 Tahun 2005 tentang guru dan dosen sehingga setiap guru mendapatkan perlindungan terhadap hak yang dimiliki dan kewajiban yang harus dilaksanakan. Dalam UU No. 14 Tahun 2005 tentang guru dan dosen pada bagian kedua mengenai hak dan kewajiban pada pasal 14, adapun hak yang dimiliki oleh seorang guru sebagai berikut:

a. Memperoleh penghasilan di atas kebutuhan hidup minimum dan jaminan kesejahteraan sosial.

b. Mendapatkan promosi dan penghargaan sesuai dengan tugas dan prestasi kerja.

c. Memperoleh perlindungan dalam melaksanakan tugas dan hak atas kekayaan intelektual.

d. Memperoleh kesempatan untuk meningkatkan kompetensi.

e. Memperoleh dan memanfaatkan sarana dan prasarana pembelajaran untuk menunjang kelancaran tugas keprofesionalan.

f. Memiliki kebebasan dalam memberikan penilaian dan ikut menentukan kelulusan, penghargaan, dan atau sanksi kepada peserta didik sesuai dengan kaidah pendidikan, kode etik guru, dan peraturan perundang-undangan.

g. Memperoleh rasa aman dan jaminan keselamatan dalam melaksanakan tugas.

h. Memiliki kebebasan untuk berserikat dalam organisasi profesi.

i. Memiliki kesempatan untuk berperan dalam penentuan kebijakan pendidikan. 
j. Memperoleh kesempatan untuk mengembangkan dan meningkatkan kualifikasi akademik dan kompetensi.

k. Memperoleh pelatihan dan pengembangan profesi dalam bidangnya.

Dalam melaksanakan tugas keprofesionalan dalam UU No. 14 tahun 2005 tentang guru dan dosen, pada pasal 20 maka guru berkewajiban sebagai berikut:

a. Merencanakan pembelajaran, melaksanakan proses pembelajaran yang bermutu, serta menilai dan mengevaluasi hasil pembelajaran.

b. Mengembangkan dan meningkatkan kualifikasi akademik dan kompetensi secara berkelanjutan sejalan dengan perkembangan ilmu pengetahuan, teknologi dan seni.

c. Bertindak objektif dan tidak diskriminatif atas dasar pertimbangan jenis kelamin, agama, suku, ras, dan kondisi fisik tertentu, atau latar belakang keluarga, dan status sosial ekonomi peserta didik dalam pembelajaran

d. Menjunjung tinggi peraturan perundang undangan, hukum dan kode etik guru, serta nilai nilai agama dan etika.

e. Memelihara dan memupuk persatuan dan kesatuan bangsa.

\section{GURU INDONESIA DAN TANTANGAN PROFESIONALISME}

Bagian Istilah profesionalisme berasal dari profession. Dalam Kamus Inggris Indonesia, 'profession' berarti pekerjaan (John M. Echols dan Hassan Shadili, 1996:449). Arifin dalam buku Kapita Selekta Pendidikan mengemukakan bahwa profession mengandung arti yang sama dengan kata occupation atau pekerjaan yang memerlukan keahlian yang diperoleh melalui pendidikan atau latihan khusus (Arifin, 1995:105). Guruguru di Indoneisa masih ada yang tidak memiliki latar belakang pendidikan bidang keguruan. Seorang guru berkaitan dengan aktivitas profesinya duharuskan mengetahui dan dapat menerapkan beberapa prinsip mengajar agar ia dapat melaksanakan tugasnya secara profesional, Keprofeionalisme sangat mempengaruhi guru dalam mengajar, bersikap, dan bersosialisai dengan masyarakat. Seorang guru dikatakan profesional bila guru itu memiliki 
kulitas pembelajaran yang tinggi. Padahal profesional mengandung makna yang lebih luas dari berkualitas tinggi dalam hal teknis (Uno, 2007: 15).

Dengan ada nya profeionalisme, untuk mencapai tugas guru untuk memajukan kehidupan bangsa, ditetapkan kemampuan guru dalam beberapa bagian, yaitu:
a. Kemampuan merencanakan pengajaran
b. Kemampuan melaksanakan prosedur mengajar
c. Kemampuan melaksanakan hubungan pribadi dengan siswa
d. Memiliki keahlian dalam bidangnya
e. Memiliki otonomi dan tanggung jawab
f. Memiliki rasa kesejawatan

Dengan adanya kemampuan profesional guru di harapkan bisa membantu menaikan derajat mutu pendidikan di tanah air. Karena Profesionalisme merupakan sikap dari seorang profesional. Artinya sebuah term yang menjelaskan bahwa setiap pekerjaan hendaklah dikerjakan oleh seseorang yang mempunyai keahlian dalam bidangnya atau profesinya.

Kompeonen kopetensi guru merupakan kemampuan dasar yang harus dimiliki oleh guru. Ada beberapa pandangan ahli tentang kompetensi profesional guru. Menurut Cooper (1984:15) terbagi kedalam 4 komponen kompetensi dasar, yakni:

a. Mempunyai pengetahuan tentang belajar dan tingkah laku manusia

b. Mempunyai pengetahuan dan menguasai bidang studi yang dibinanya

c. Mempunyai sikap yang tepat tentang diri sendiri, sekolah, teman sejawat dan bidang studi yang dibinanya

d. Mempunyai keterampilan dalam tekhnik mengajar

Sedangkan menurut Depdibud (1980) ada 10 kemampuan dasar guru, yaitu:
a. Penguasaan bahan pelajaran beserta konsep-konsep dasar keilmuannya
b. Pengelolaan program belajar mengajar
c. Pengelolaan kelas
d. Penggunaan media dan sumber pembelajaran 
e. Penguasaan landasan-landasan kependidikan

f. Pengelolaan interaksi belajar mengajar

g. Penilaian prestasi siswa

h. Pengenalan fungsi dan program bimbingan dan penyuluhan

i. Pengenalan dan penyelenggaraan administrasi sekolah serta

j.Pemahaman prinsip-prinsip dan pemanfaatan hasil penelitian pendidikan untuk kepentingan peningkatan mutu pengajaran.

\section{SIMPULAN}

Pada hakikatnya Profesi guru merupakan profesi yang sangat mulia karena mereka berusaha sebaik mungkin dengan kemampuan profesi agar memajukan mutu pendidikan di Indoneisa. Guru adalah pendidik profesional dengan tugas utama mendidik, mengajar, membimbing, mengarahkan, melatih, menilai, dan mengevaluasi peserta didik pada pendidikan anak usia dini jalur pendidikan formal, pendidikan dasar, dan pendidikan menengah. Untuk mendapatkan profesi guru juga bukanlah hal yang mudah, ada pelatihan khusus nya untuk bisa mendapatkan gelar guru yang profeisonal.

\section{REFERENSI}

Efendi, I., Prawitasari, M., \& Susanto, H. (2021). Implementasi Penilaian Pembelajaran Pada Kurikulum 2013 Mata Pelajaran Sejarah. Prabayaksa: Journal of History Education, 1(1), 21-25.

Susanto, H. (2020). Profesi Keguruan. Banjarmasin: FKIP Universitas Lambung Mangkurat.

Susanto, H., \& Akmal, H. (2018). Efektivitas Penggunaan Aplikasi Pembelajaran Berbasis Mobile Smartphone Sebagai Media Pengenalan Sejarah Lokal Masa Revolusi Fisik Di Kalimantan Selatan Pada Siswa Sekolah Menengah Atas. HISTORIA: Jurnal Program Studi Pendidikan Sejarah, 6(2), 197-206.

Susanto, H., Irmawati, I., Akmal, H., \& Abbas, E. W. (2021). Media Film Dokumenter Masuknya Islam Ke Nusantara dan Pengaruhnya Terhadap Keterampilan Berpikir Kritis Siswa. HISTORIA: Jurnal Program Studi Pendidikan Sejarah, 9(1). 
Syaharuddin, S., \& Susanto, H. (2019). Sejarah Pendidikan Indonesia (Era Pra Kolonialisme Nusantara sampai Reformasi). Banjarmasin: FKIP Universitas Lambung Mangkurat.

Rahardjo, Mudjia. (2010). Profesi dan Profesionalisasi Keguruan. Jurnal : UIN MAULANA MALIK IBRAHIM MALANG. https://www.uinmalang.ac.id/r/100401/profesi-dan-profesionalisasi-keguruan.html atau www.mudjiarahardjo.com

Mustofa. (2007). Upaya Pengembangan Profesionalisme Guru di Indonesia. Jurnal : EKONOMI DAN PENDIDIKAN. Vol. 4 No.1. https://journal.uny.ac.id/index.php/jep/article/view/619

\section{INTERNET}

https://eprints.uny.ac.id/7786/3/bab\%202\%20-\%20\%2008108249111.pdf

http://digilib.uinsby.ac.id/6465/2/Bab\%201.pdf

https://pintek.id/blog/kompetensi-guru/ 